\title{
Functional analysis of microbial communities in aerobic-anaerobic sequencing batch reactors fed with different phosphorus/carbon (P/C) ratios
}

\author{
Yun H. Kong, ${ }^{1}$ Michael Beer, ${ }^{1}$ Gavin N. Rees ${ }^{2}$ and Robert J. Seviour ${ }^{1}$
}

Author for correspondence: Robert J. Seviour. Tel: +6135 444 7459. Fax: +61354447476. e-mail: r.seviour@latrobe.edu.au

1 Biotechnology Research Centre, La Trobe University, Bendigo, 3552 Victoria, Australia

2 Murray-Darling Freshwater Research Centre and CRC for Freshwater Ecology, Albury, 2640 NSW, Australia

\begin{abstract}
Fluorescence in situ hybridization (FISH) was used to analyse the community composition of a sequencing batch reactor (SBR) operating with aerobic-anaerobic cycling and fed acetate as its sole carbon source. Phosphorus was removed from the SBR microbiologically. Marked shifts in the community structure occurred as the phosphorus/carbon $(P / C)$ ratio in the feed was changed. When the P/C ratio was shifted from 1:10 to 1:50, FISH analysis showed that the percentage of $\beta$-Proteobacteria fell from ca $77 \%$ of the total bacteria to ca $38 \%$. This decrease in the $\beta$-Proteobacteria coincided with a reduction in both the proportions of the $\beta$-proteobacterial Rhodocyclus-related phosphorus-accumulating bacteria and the biomass phosphorus content. FISH/microautoradiography and FISH/poly $\beta$-hydroxyalkanoate (PHA) staining showed that the Rhodocyclus-related bacteria assimilated acetate and synthesized PHAs anaerobically, and that they accumulated phosphorus aerobically. No Acinetobacter spp. could be detected in any of the communities, casting further doubt on their role in phosphorus-removing activated sludge systems. As the feed P/C ratio decreased there was a corresponding increase in the proportion of $\alpha$-Proteobacteria and, to a smaller extent, in the proportion of $\gamma$-Proteobacteria; both the $\alpha$ - and $\gamma$-Proteobacteria consisted mostly of tetrad-forming cocci, fitting the description of the so-called ' G-bacteria' morphotype. The change in the proportions of Proteobacteria present paralleled increases in the biomass glycogen content. Both the $\alpha$ - and $\beta$-proteobacterial ' G-bacterial' populations assimilated acetate and synthesized PHA anaerobically. The $\alpha$-Proteobacteria are considered responsible for glycogen production in these SBR systems.
\end{abstract}

Keywords: enhanced biological phosphorus removal (EBPR), 'G-bacteria', fluorescence in situ hybridization/microautoradiography (FISH/MAR), Rhodocyclus

\section{INTRODUCTION}

Activated sludge systems that remove phosphorus all have a common operating feature in that the biomass is cycled through alternating aerobic-anaerobic reactors (Mino et al., 1998). Despite their widespread application, the microbiology of these systems is still poorly

\footnotetext{
Abbreviations: EBPR, enhanced biological phosphorus removal; FISH, fluorescence in situ hybridization; GAB, glycogen-accumulating bacteria; MAR, microautoradiography; $\mathrm{PAB}$, phosphorus-accumulating bacteria; $\mathrm{P} / \mathrm{C}$ phosphorus/carbon; PHA, poly $\beta$-hydroxyalkanoate; PHB, poly $\beta$-hydroxybutyrate; SBR, sequencing batch reactor.
}

understood. Acinetobacter spp., from the $\gamma$-Proteobacteria, were thought to play an important role in enhanced biological phosphorus removal (EBPR) activated sludge systems. However, data obtained from several molecular studies (Crocetti et al., 2000; Hesselmann et al., 1999; Liu et al., 2001) have cast doubt on a significant role for acinetobacters in EBPR. Instead, bacteria closely related to members of the genus Rhodocyclus, in the $\beta$-Proteobacteria, are now attracting interest as possible phosphorus-accumulating bacteria $(\mathrm{PAB})$. They have been enriched in laboratory-scale sequencing batch reactors (SBRs), their $16 \mathrm{~S}$ rRNA genes have been cloned and sequenced and 16S-rRNA-targeted 
oligonucleotide probes have been designed for their in situ identification. It is unlikely that these are the only $\mathrm{PAB}$, and other bacteria belonging to the $\alpha$ - and $\gamma$ Proteobacteria and members of the high-G + C Grampositive bacteria have all been implicated in EBPR (Bond et al., 1995; Kawaharasaki et al., 1999; Liu et al., 2001; Wagner et al., 1994).

As well as the PAB, other physiological groups of bacteria can dominate aerobic-anaerobic activated sludge systems and these include the so-called ' $\mathrm{G}$ bacteria', a term used here to describe a morphotype of cocci usually arranged in tetrads and/or clusters. These 'G-bacteria' are now known to be phylogenetically diverse (Seviour et al., 2000). Cocci fitting this morphotype description and seen in large numbers in some aerobic-anaerobic activated sludge systems have been referred to as glycogen-accumulating bacteria (GAB) (Mino et al., 1998), even though their abilities to accumulate glycogen have not been determined. Heterotrophic lactic acid bacteria have also been detected as dominating populations in SBR systems fed a mixture of glucose and acetate (Kong et al., 2001). Understanding the possible relationships between the $\mathrm{PAB}$ and ' $\mathrm{G}$ bacteria' has attracted interest, since 'G-bacteria' have been considered responsible, in some studies, for the failure of EBPR systems by out-competing the PAB for substrates in the anaerobic phase of these aerobicanaerobic systems (Cech \& Hartman, 1993). However, which of the different 'G-bacteria', if any, might be responsible for EBPR failure is not known (Seviour et al., 2000). The original 'G-bacteria' candidate of Cech \& Hartman (1993), Amaricoccus kaplicensis (Maszenan et al., 1997), is absent from aerobic-anaerobic SBRs fed a mixture of glucose and acetate and showing no EBPR (Kong et al., 2001); pure cultures of this organism also fail to demonstrate any ability for anaerobic glucose and acetate assimilation (Falvo et al., 2001; Y. H. Kong \& R. J. Seviour, unpublished data).

Liu et al. (1997) proposed that the GAB and PAB can coexist in some aerobic-anaerobic SBR systems. Their relative dominance was determined by the phosphorus/ carbon $(\mathrm{P} / \mathrm{C})$ ratios in the influent feed. Higher $\mathrm{P} / \mathrm{C}$ ratios favoured the $\mathrm{PAB}$, whereas lower ones favoured the GAB. These bacteria were not identified, although cells resembling 'G-bacteria' dominated these communities upon microscopic examination. No molecular methods were used in the study of Liu et al. (1997) to analyse the composition of the two different microbial communities, hence the identities of the PAB and GAB were not resolved. Furthermore, data linking the chemical changes occurring in the reactors fed different influents to specific populations in the biomass were not obtained. In this study, fluorescence in situ hybridization (FISH)/microautoradiography (MAR) was used to elucidate the relationships between the structure and function of bacterial communities within aerobic-anaerobic SBR systems (Gray \& Head, 2001), to resolve the composition of the PAB and 'G-bacterial' populations and to understand their roles in anaerobic substrate assimilation and storage-polymer production.

\section{METHODS}

SBRs and operational conditions used in this study. The details for these have been given previously (Kong et al., 2001). The SBR was operated in an air-conditioned laboratory maintained at $21^{\circ} \mathrm{C}\left( \pm 1^{\circ} \mathrm{C}\right)$, with four $6 \mathrm{~h}$ cycles per day. Each $6 \mathrm{~h} \mathrm{SBR}$ cycle consisted of (in order) an anaerobic period of $120 \mathrm{~min}$, including a $3 \mathrm{~min}$ filling period, an aerobic period of $190 \mathrm{~min}$, a settling period of $44 \mathrm{~min}$ and a draw period of $6 \mathrm{~min}$. The SBR was seeded with biomass taken from an EBPR plant that was actively removing phosphorus (Castlemaine, Victoria, Australia). During the aerobic phase, the $\mathrm{pH}$ was kept between $7 \cdot 1$ and $7 \cdot 3$ using $\mathrm{pH}$ controllers (TPS process controller, Model 88) by adding $0.5 \mathrm{M} \mathrm{H}_{2} \mathrm{SO}_{4}$ or $0.5 \mathrm{M} \mathrm{NaOH}$. No pH control was exerted during the anaerobic phase. The feed consisted of $\left(1^{-1}\right): 683 \mathrm{mg}$ anhydrous sodium acetate; $100 \mathrm{mg} \mathrm{NaCl} ; 50 \mathrm{mg} \mathrm{CaCl} .2 \mathrm{H}_{2} \mathrm{O} ; 200 \mathrm{mg} \mathrm{MgSO}_{4} .7 \mathrm{H}_{2} \mathrm{O}$; $100 \mathrm{mg}\left(\mathrm{NH}_{4}\right)_{2} \mathrm{SO}_{4}$. The amount of $\mathrm{KH}_{2} \mathrm{PO}_{4}$ added to the feed varied from run to run $\left[\mathrm{Run} \mathrm{P} 1,20 \mathrm{mg} \mathrm{l}^{-1}\right.$ (P/C ratio 1:10); Run P2, $10 \mathrm{mg} \mathrm{l}^{-1}(\mathrm{P} / \mathrm{C}$ ratio $1: 20)$; Run P3, $4 \mathrm{mg} \mathrm{l}^{-1}$ $(\mathrm{P} / \mathrm{C}$ ratio $1: 50)]$. The medium was supplemented with $2 \mathrm{ml} \mathrm{l}^{-1}$ of the trace element solution of Hesselmann et al. (1999). 1-Allyl-2-thiourea $\left(5 \mathrm{mg} \mathrm{l}^{-1}\right)$ was added to suppress nitrification. For each run, the SBR was operated for 4-6 months before 'steady state' conditions were achieved; it was assumed that these had been reached when all of the chemical parameters used to monitor the SBR showed no marked changes between repeated samples taken over a 3-week period. After characterization of the 'steady state' biomass from Run $\mathrm{P} 1$, the $\mathrm{P} / \mathrm{C}$ ratio in the feed was changed to $1: 20$ (Run P2). The SBR was then run under these conditions for another 4-6 months until 'steady state' was achieved and the biomass was again characterized. The feed conditions were then altered to give a P/C ratio of 1:50 (Run P3), the SBR was operated until 'steady state' was achieved and upon attainment of this state the biomass was again analysed. At each 'steady state', samples were removed during three SBR cycles for analyses; these were taken at least at 1-week intervals (Kong et al., 2001).

Anaerobic batch trials. These were performed, as described previously (Kong et al., 2001), to measure the capacity of the biomass taken from the SBR run with different feed P/C ratios for anaerobic glucose assimilation. Samples were taken for analyses and handled and stored in the same way as those used for samples from the SBR cycles as described previously (Kong et al., 2001).

Chemical analyses of samples. All of the methods used for the chemical analyses of samples taken from the SBR and anaerobic batch trials, including those for poly $\beta$-hydroxyalkanoate (PHA) and glycogen, were as described previously (Kong et al., 2001).

FISH of biomass samples. The 16S-rRNA-targeted oligonucleotide probe sequences used for FISH in this study are listed in Table 1. The conditions of stringency and permeabilization procedures, if required, were those described originally for each probe. Biomass samples for FISH were fixed in paraformaldehyde (Amann, 1995) or in absolute ethanol (Roller et al., 1994) for Gram-negative and Gram-positive bacteria, respectively. All FISH procedures were performed according to Amann (1995).

FISH/MAR methodology. FISH/MAR was carried out using the methods detailed by Kong et al. (2001), which were essentially those described by Lee et al. (1999). Appropriate controls for substrate adsorption and chemotrophy were incorporated into the protocol, as detailed previously (Kong et al., 2001). D-[6- $\left.{ }^{3} \mathrm{H}\right]$ Glucose and sodium $\left[2-{ }^{14} \mathrm{C}\right]$ acetate were 
Table 1. Oligonucleotide probes used for FISH analysis in this study

\begin{tabular}{|c|c|c|c|}
\hline Bacteria probed & Probe used & Probe sequence $(s)\left(5^{\prime} \rightarrow 3^{\prime}\right)$ & Reference \\
\hline$\beta$-Proteobacteria & Beta42a & GCCTTCCCACTTCGTTT & Manz et al. (1992) \\
\hline Rhodocyclus-related PAB & PAO651 & CССТСТGCСAAACTCCAG & Crocetti et al. (2000) \\
\hline$\alpha$-Proteobacteria & ALF968 & GGTAAGGTTCTGCGCGTT & Neef et al. (1999) \\
\hline$\gamma$-Proteobacteria & GAM42a & CCCTTCCCACATCGTTT & Manz et al. (1992) \\
\hline Some $\gamma$-Proteobacteria & $\gamma-1019$ & GGTTCCTTGCGGCACCTC & Nielsen et al. (1999) \\
\hline Some $\gamma$-Proteobacteria & $\gamma-1278$ & ACGAGCGGCTTTTTGGGATT & Nielsen et al. (1999) \\
\hline High-G $+\mathrm{C}$ bacteria & HGC69a & TATAGTTACCACCGCCGT & Roller et al. (1994) \\
\hline Amaricoccus spp. & MAR839 & CTGCGACACCGAACGGCAAGCC & Maszenan et al. (2000b) \\
\hline D. vanus & DEF438 & CGCCTGAGACGATGATGAC & Kong et al. (2001) \\
\hline M. glycogenica & MIC184 & CATTCCTCAAGTCTGCC & Kong et al. (2001) \\
\hline Tetrasphaera spp. & TET63 & GCTCCAGGGTCACCGTTC & Kong et al. (2001) \\
\hline Low-G $+C$ bacteria & LGC354A & TGGAAGATTCCCTACTGC & Meier et al. (1999) \\
\hline Low-G $+\mathrm{C}$ bacteria & LGC354B & CGGAAGATTCCCTACTGC & Meier et al. (1999) \\
\hline Low-G $+C$ bacteria & LGC354C & GAAGATTCCCTACTGCCC & Meier et al. (1999) \\
\hline GAB & GAOQ 431 & CGCGGCTCTGACGTTACC & Crocetti et al. (2001) \\
\hline Bacteria & EUB 338 & GCTGCCTCCCGTAGGAGT & Amann et al. (1995) \\
\hline Bacteria & EUB mix & $\begin{array}{l}\text { GCAGCCACCCGTAGGTGTGCT } \\
\text { GCCACCCGTAGGTGT }\end{array}$ & Daims et al. (1999) \\
\hline
\end{tabular}

incubated with biomass samples taken from the end of the SBR anaerobic cycle at concentrations of $74 \mathrm{kBq}[\mathrm{mg}$ mixed liquor suspended solids (MLSS) $]^{-1}$ and $1 \mathrm{mM}$, respectively, as described by Kong et al. (2001). For aerobic ${ }^{33} \mathrm{P}$ assimilation experiments, the methods of Lee et al. (1999) were also used. A $2 \mathrm{ml}$ aliquot of mixed liquor $\left(2 \mathrm{~g} \mathrm{MLSS}^{-1}\right)$ taken from the end of the anaerobic phase of the SBR cycle was incubated with $370 \mathrm{kBq}^{33} \mathrm{PO}_{4}^{3-}(\mathrm{mg} \mathrm{MLSS})^{-1}$ and shaken vigorously at $20^{\circ} \mathrm{C}$ for $4 \mathrm{~h}$. The intensity of silver grain deposition on the surface of cells was kept deliberately low by empirically adjusting the incubation and development times for emulsioncoated slides. If there was too much deposition, the fluorescent signal after FISH was quenched and in situ identification of populations of cells was not always possible. Hence, the exposure times of the emulsion to biomass samples were empirically adjusted to between 3 and 7 days at $4{ }^{\circ} \mathrm{C}$; development times of $0 \cdot 5-5 \mathrm{~min}$ were usually adopted. If no silver particle deposition was seen, the emulsion and development times were extended to up to 10 days and $10 \mathrm{~min}$, respectively, to confirm that no substrate assimilation was taking place. All radiochemicals were purchased from Amersham Pharmacia Biotech, with initial specific activities for ${ }^{33} \mathrm{P}$ (as $\mathrm{NaH}_{2} \mathrm{PO}_{4}$ ), D- $\left[6-{ }^{3} \mathrm{H}\right]$ glucose and sodium $\left[2-{ }^{14} \mathrm{C}\right]$ acetate of $>111 \mathrm{GBq} \mathrm{mmol}^{-1}, 1.07 \mathrm{TBq} \mathrm{mmol}^{-1}$ and $2.07 \mathrm{GBq} \mathrm{mmol}^{-1}$, respectively.

Identification of bacterial populations accumulating PHA. The methods used to identify cells in biomass samples taken from the end of the SBR anaerobic cycle that were capable of accumulating poly $\beta$-hydroxybutyrate $(\mathrm{PHB})$ were those described by Liu et al. (2001).

Staining methods and microscopy. The Gram and methylene blue staining protocols of Lindrea et al. (1999) were used in this study. Stained samples were examined under a Nikon microscope (Eclipse E800). All specimens for FISH were mounted in Vectashield (Vector Laboratories) and viewed under a Nikon epifluorescence microscope with the appropriate filter blocks for the fluorochromes used. Colour photographs and Nomarski photographs were taken automatically with a Nikon V-TP micrography module.
Enumeration of bacteria after FISH probing. Digital images for quantifying the bacteria that responded positively to probes were captured with a CompuScope CCD 1600 12HS digital camera installed on a Nikon microscope, which was used with an oil immersion objective lens. The digital camera was controlled by ProControl software (High Performance 32 bit Scientific Image Processing), and the images obtained were prepared in Adobe Photoshop before being analysed with NIH image (Kong et al., 2001). Cells fluorescing with a given FISH probe were expressed as a percentage of the total area of bacteria giving a signal with the EUB 338 probe of Amann et al. (1995) or the EUB mix probes of Daims et al. (1999) in the same field. The percentage of the total number of cells detected with 4',6-diamidino-2-phenyindole (DAPI) that fluoresced with the EUB 338 and the EUB mix probes was very similar in these biomass samples, being $96.1 \%( \pm 5 \%)$ and $96.6 \%( \pm 9.8 \%)$, respectively $(n=25)$. At least eight randomly selected fields containing an estimated more than two thousand cells in total were examined for each sample and probe. The numbers obtained were averaged and expressed as a percentage of the total DAPI-stained bacteria in the microbial community. An allowance was made for the larger $\alpha$ - and $\gamma$-proteobacterial 'G-bacteria' in these determinations, as detailed by Kong et al. (2001).

\section{RESULTS}

\section{Chemical changes occurring in SBRs in response to changing $\mathrm{P} / \mathrm{C}$ ratio}

The chemical changes occurring in the SBR cycles of Runs P1 (P/C ratio $1: 10), \mathrm{P} 2$ (P/C ratio $1: 20)$ and $\mathrm{P} 3$ $(\mathrm{P} / \mathrm{C}$ ratio $1: 50)$ at 'steady state' are shown in Fig. 1 and the main features are summarized in Table 2. During the anaerobic phase in all three runs, acetate was utilized rapidly, an event which corresponded to the consumption of glycogen and the synthesis of PHA, consisting in each case of $\mathrm{PHB}$ and poly $\beta$-hydroxyvalerate. The relative amounts of PHB and poly $\beta$-hydroxyvalerate 
(a)

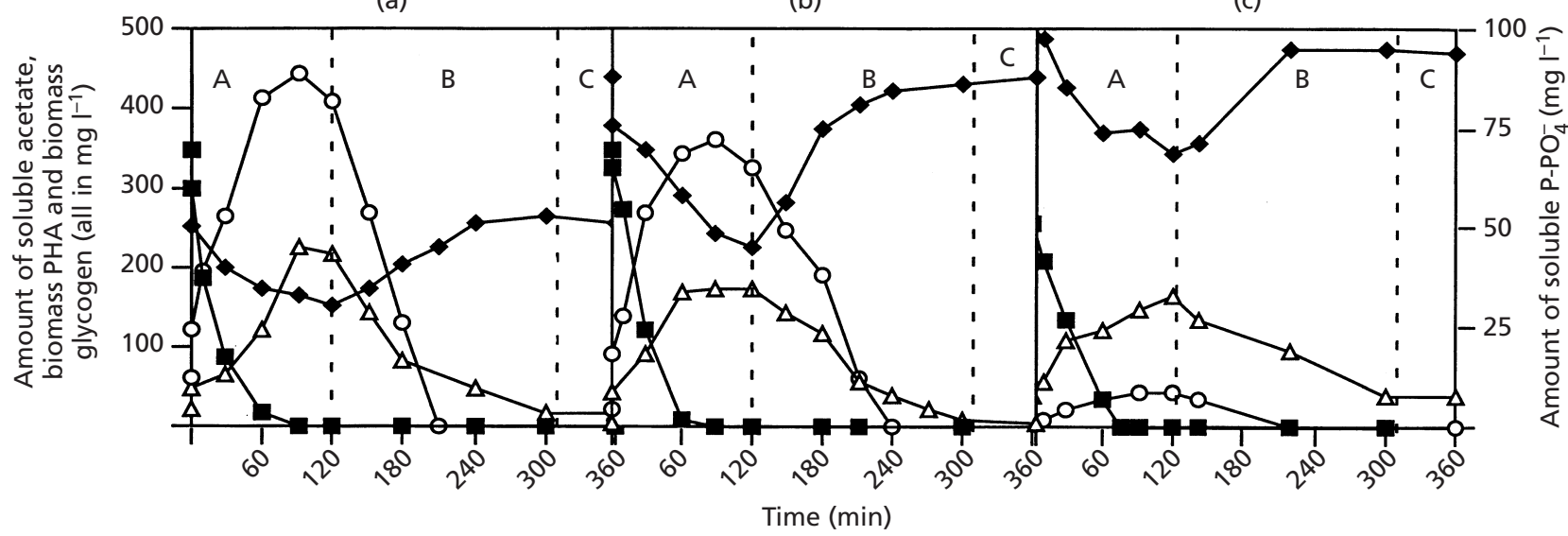

Fig. 1. Chemical changes occurring during the SBR cycles of (a) Run $P 1$ (P/C 1:10), (b) Run $P 2$ (P/C 1:20) and (c) Run $P 3$ (P/C 1:50) at 'steady state' conditions. Q, Soluble acetate $\left(\mathrm{mg} \mathrm{I}^{-1}\right) ; \triangle$, biomass PHA ( $\left.\mathrm{mg} \mathrm{I}^{-1}\right)$; $\diamond$, biomass glycogen $\left(\mathrm{mg} \mathrm{l}^{-1}\right) ; \mathrm{O}$, soluble $\mathrm{P}_{-} \mathrm{PO}_{4}^{-}\left(\mathrm{mg} \mathrm{l}^{-1}\right)$. A, anaerobic phase; $\mathrm{B}$, aerobic phase; $\mathrm{C}$, settle period.

Table 2. Chemical changes carried out by 'steady state' biomass during the anaerobic phase of the SBR fed with different P/C ratios

\begin{tabular}{|c|c|c|c|}
\hline \multirow[t]{2}{*}{ Variable* } & \multicolumn{3}{|c|}{ Run } \\
\hline & $\mathrm{P} 1(\mathrm{P} / \mathrm{C}=1: 10) \dagger$ & $\mathrm{P} 2(\mathrm{P} / \mathrm{C}=1: 20) \dagger$ & $\mathrm{P3}(\mathrm{P} / \mathrm{C}=1: 50) \dagger$ \\
\hline \multicolumn{4}{|l|}{ Acetate utilization: } \\
\hline Quantity [mg C (g VSS) $\left.)^{-1}\right]$ & $34 \cdot 9$ & $34 \cdot 8$ & $41 \cdot 3$ \\
\hline Rate $\left[\mathrm{mg} \mathrm{C}\left(\mathrm{g} \mathrm{VSS}^{-1} \mathrm{~h}^{-1}\right]\right.$ & $32 \cdot 2$ & $32 \cdot 1$ & $33 \cdot 0$ \\
\hline $\begin{array}{l}\text { Glycogen consumption } \\
{\left[\mathrm{mg} \mathrm{C}(\mathrm{g} \mathrm{VSS})^{-1}\right]}\end{array}$ & $13 \cdot 5(0 \cdot 4)$ & $27 \cdot 8(0 \cdot 8)$ & $25 \cdot 9(1 \cdot 1)$ \\
\hline PHA production $\left[\mathrm{mg} \mathrm{C}\left(\mathrm{g} \mathrm{VSS}^{-1}\right]\right.$ & $71 \cdot 5$ & $55 \cdot 8$ & $52 \cdot 1$ \\
\hline $\mathrm{PHB}(\%)$ & 68 & 67 & 75 \\
\hline $\operatorname{PHV}(\%)$ & 32 & 33 & 25 \\
\hline \multicolumn{4}{|l|}{$P$ released: } \\
\hline Quantity [mg (g VSS $)^{-1}$ ] & $27 \cdot 0$ & $21 \cdot 4$ & $2 \cdot 4$ \\
\hline Rate $\left[\mathrm{mg}(\mathrm{g} \mathrm{VSS})^{-1} \mathrm{~h}^{-1}\right]$ & $27 \cdot 0$ & $21 \cdot 4$ & $1 \cdot 6$ \\
\hline Biomass $\mathrm{P}$ content $(\%, \mathrm{w} / \mathrm{w}) \ddagger$ & $8 \cdot 6(0 \cdot 1)$ & $6 \cdot 4(0 \cdot 1)$ & $2 \cdot 5(0 \cdot 1)$ \\
\hline Biomass glycogen levels $(\%, w / w) \neq$ & $7 \cdot 5(0 \cdot 2)$ & $12 \cdot 5(0 \cdot 3)$ & $16 \cdot 9(0 \cdot 9)$ \\
\hline
\end{tabular}

*VSS, volatile suspended solids; PHV, poly $\beta$-hydroxyvalerate.

† Values in parentheses represent the SD calculated from four glycogen or three biomass P content determinations.

¥Values detected at the end of the aerobic phase of the SBR standard cycle of each run.

were the same in the biomass samples from Runs P1 and P2 (Table 2). As predicted from the models of EBPR systems (Mino et al., 1998), phosphorus was also released, until all of the influent acetate was consumed. Once all of the acetate had been consumed, a small amount of anaerobic phosphorus uptake then occurred in all three SBR runs (Fig. 1). The reasons for this are not known, but similar trends have been seen in other similar studies (Crocetti et al., 2000; Hesselmann et al., 1999). Both the amount and rate of phosphorus release from the biomass samples fell at the lower feed P/C ratios (Table 2). During the subsequent aerobic phases, a decrease in the PHA levels in all three SBR runs corresponded to the assimilation of phosphorus and an increase in glycogen levels in the biomass. An increasing glycogen and decreasing biomass phosphorus content was detected as the $\mathrm{P} / \mathrm{C}$ ratios fell (Table 2 ). Biomass glycogen and phosphorus levels were $8.6 \%(\mathrm{w} / \mathrm{w})$ and $7 \cdot 5 \%(\mathrm{w} / \mathrm{w})$ in Run P1 (1:10), $12.4 \%(\mathrm{w} / \mathrm{w})$ and $6.4 \%$ $(\mathrm{w} / \mathrm{w})$ in Run P2 $(1: 20)$ and $16.7 \%(\mathrm{w} / \mathrm{w})$ and $2.5 \%$ (w/w) in Run P3 (1:50), respectively. After up to $2 \mathrm{~h}$ incubation, no glucose assimilation (Kong et al., 2001) 


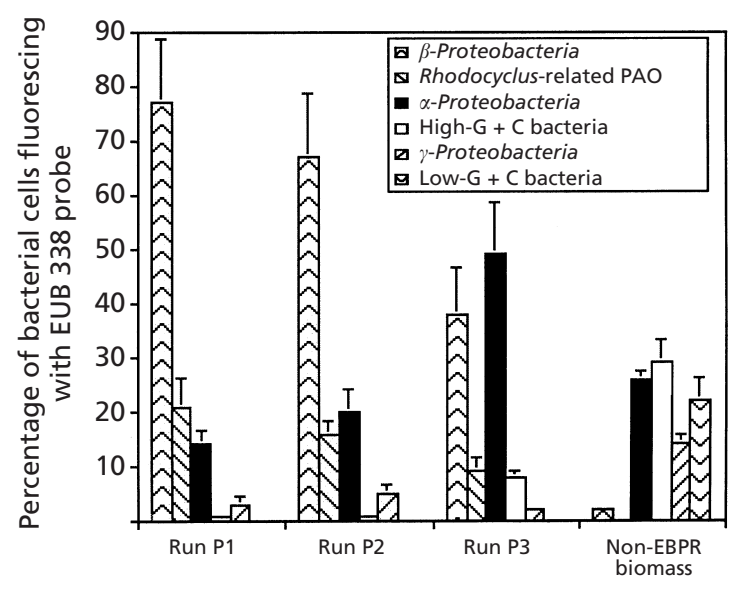

Fig. 2. Changes in microbial populations from FISH analysis of biomass samples from SBR runs with different $\mathrm{P} / \mathrm{C}$ ratios in the feed. Data are from Runs $P 1(P / C=1: 10), P 2(P / C=1: 20)$ and $P 3$ $(P / C=1: 50)$ (this study) and a non-EBPR biomass fed a mixture of glucose and acetate (Kong et al., 2001). Error bars on each column represent the SD from at least eight counts of the specific populations represented as percentages of the total area fluorescing with DAPI.

was recorded in biomass samples removed at the end of the aerobic phase of each of the SBRs when pulsed anaerobically with glucose.

\section{Composition of the microbial communities in response to different feed $\mathrm{P} / \mathrm{C}$ ratios}

The morphological features of the biomass from all three SBRs were found to be similar upon microscopic examination. However, methylene blue staining indi-

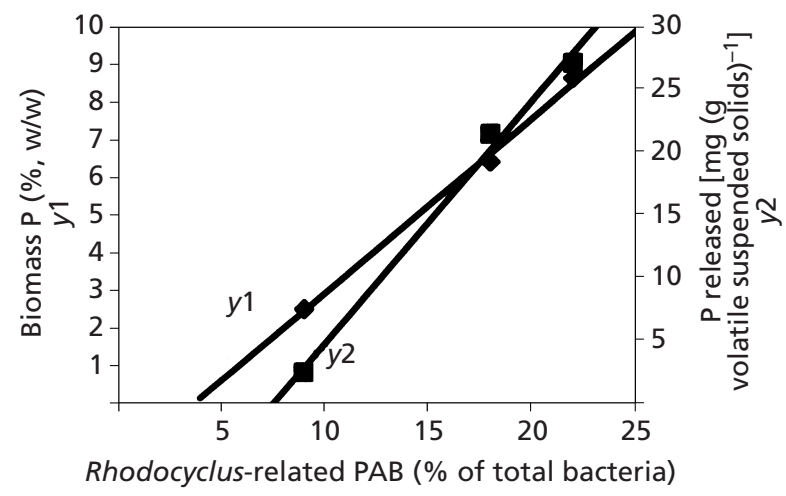

Fig. 4. Relationships between the abundance of Rhodocyclusrelated $P A B$ and the biomass $P$ content and the abundance of Rhodocyclus-related $\mathrm{PAB}$ and the amount of $\mathrm{P}$ released anaerobically. Biomass $\mathrm{P}$ content $(y 1 ; y 1=0.4 x-1 \cdot 7$, $\left.R^{2}=0.99\right) ; \quad, \mathrm{P}$ released anaerobically $(y 2 ; y 2=1.9 x-14.6$, $\left.R^{2}=0.99\right) . R^{2}$ is the regression coefficient for each of the lines drawn.

cated that metachromatic coccobacilli of different sizes dominated the biomass samples in Runs P1 and P2, but not in Run P3. Tetrad-forming cocci (i.e. 'G-bacteria') that did not stain metachromatically also appeared in large numbers and were much more dominant in the biomass from Run P3 than in the other biomass samples. FISH analysis of the biomass from each SBR demonstrated that the composition of the community in Run P3 was substantially different to the communities from Runs P1 and P2 (Fig. 2). The $\beta$-Proteobacteria dominated in the biomass from Runs P1 and P2, and in both runs
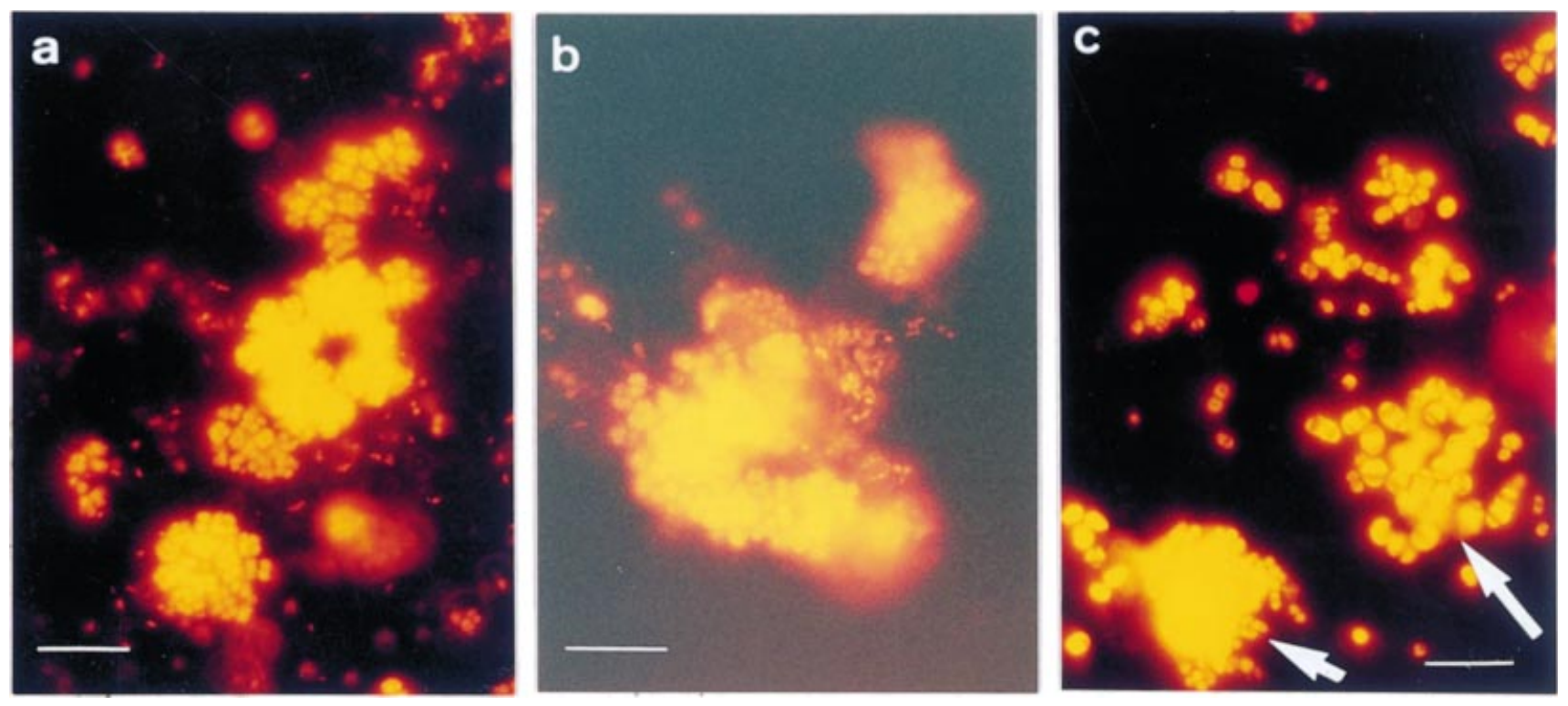

Fig. 3. Epifluorescence micrographs of Run P1 SBR biomass after FISH analysis showing large cocci in tetrads or clusters fluorescing with probes ALF968 (a) and GAM42a (b). Small cocci (short arrow) and large coccobacilli (long arrow) fluorescing with probe PAO651 (c) are also shown. Bars, $10 \mu \mathrm{m}$. 

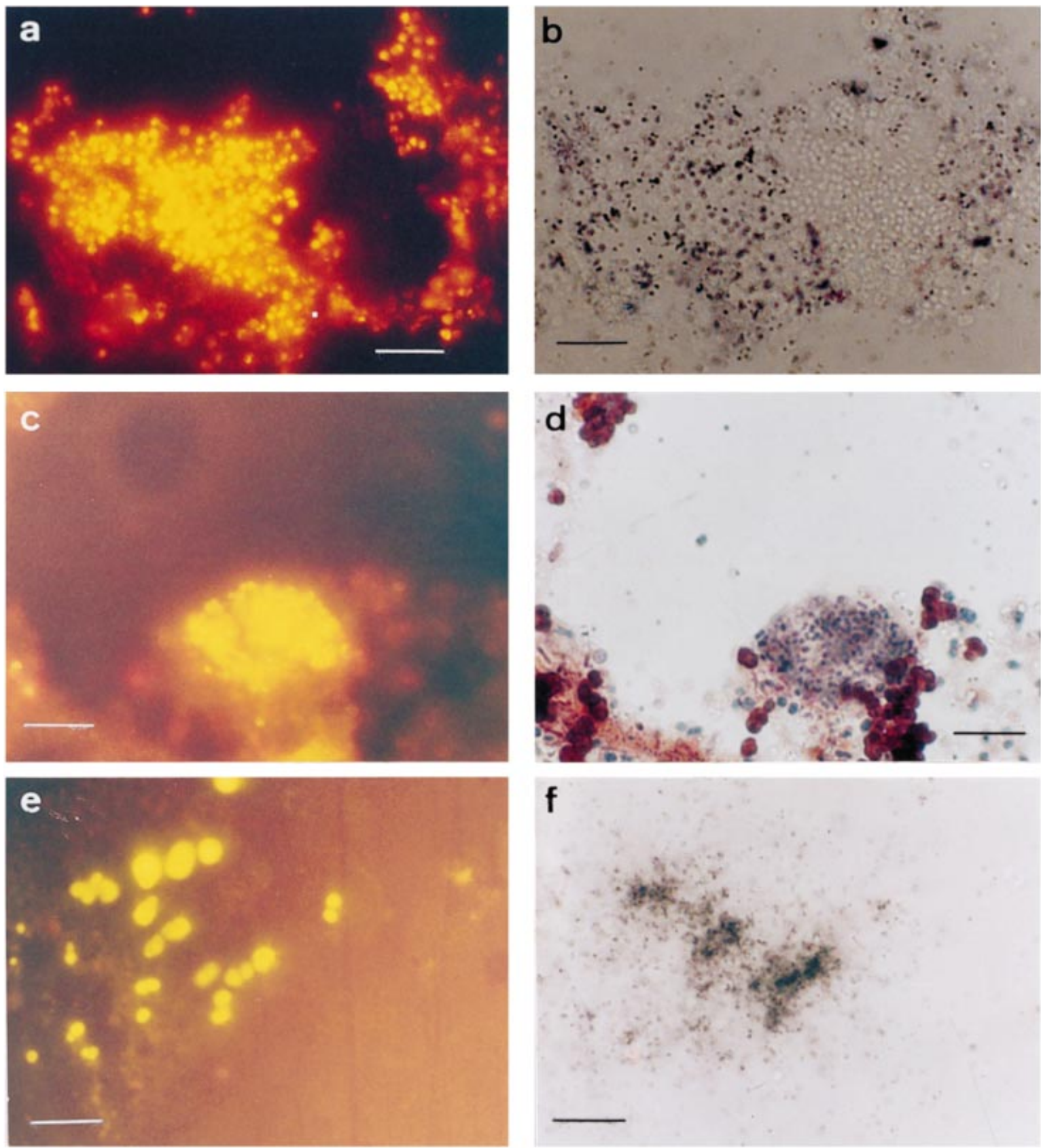

Fig. 5. Photomicrographs of biomass samples after FISH/MAR showing substrate assimilation by probed populations. (a, b) Anaerobic $\left[{ }^{14} \mathrm{C}\right]$-acetate assimilation in cells from Run P1 fluorescing with the PAO651 probe for Rhodocyclus-related PAB. Not all of the probe-positive cells showed $\left[{ }^{14} \mathrm{C}\right]$-acetate assimilation. (c, d) Anaerobic PHA accumulation in clustered cells from Run P1 fluorescing with the PAO651 probe. $(e, f)$ Aerobic ${ }^{33} \mathrm{P}$ assimilation in clustered cells from Run P2 fluorescing with the PAO651 probe. (b) Is the microautoradiograph that corresponds to the epifluorescent micrograph shown in (a). (d) Is the light micrograph of cells stained for PHA that corresponds to the epifluorescent micrograph shown in (c). (f) Is the microautoradiograph that corresponds to the epifluorescent micrograph shown in (e). Bars, $10 \mu \mathrm{m}$.

the cells appeared mainly as cocci and coccobacilli, although a few rod-shaped cells also responded to EUB 338. However, in Run P3 when the P/C ratio in the feed was $1: 50$, the percentage of the $\beta$-Proteobacteria relative to the total number of bacterial cells was ca $38 \%$ compared to ca $77 \%$ in the biomass when the feed P/C ratio was $1: 10$. At the same time the percentages of the $\alpha$ - and $\gamma$-Proteobacteria increased markedly from ca 14 to $49 \%$ and from ca 1 to $8 \%$, respectively. Almost all of these were large tetrad-forming cocci, i.e. 'G-bacteria' (Fig. 3a, b). The high-G $+\mathrm{C}$ Gram-positive bacteria were always only present in relatively small numbers 
and little change was seen in their percentages as the feed $\mathrm{P} / \mathrm{C}$ ratios changed (Fig. 2).

Of the $\beta$-Proteobacteria, large numbers of the Rhodocyclus-related PAB were detected with the PAO651 probe and they appeared as both large and small cocci and coccobacilli, usually in distinctive clusters (Fig. 3c). Their relative numbers also fell with a decrease in the feed $\mathrm{P} / \mathrm{C}$ ratios (Fig. 2), a change that corresponded to a decline in the EBPR capacity of these communities (Fig. 4). Of the $\alpha$-proteobacterial 'G-bacteria', only very small numbers ( $<1 \%$ of the total EUB-probed cells) of either Amaricoccus spp. or Defluvicoccus vanus were detected by FISH in all three biomasses. Where seen, Amaricoccus spp. appeared as large cocci in tetrads (i.e. typical 'G-bacteria'), whereas the D. vanus cells were much smaller clustered cocci (data not shown). None of the $\gamma$-Proteobacteria in the three run communities responded to the ACA 23a probe for Acinetobacter spp. or to probes designed against the large unidentified cocci seen in a failing EBPR laboratory reactor by Nielsen $e t$ al. (1999). Similarly, none of the 'G-bacteria' responded to the GAOQ 431 probe, which was designed against supposed glycogen-accumulating Gram-negative cocci of uncertain phylogenetic affiliation (Crocetti et al., 2001). Among the high-G + C Gram-positive bacteria, no cells responded to the probes for Micropruina glycogenica or for Tetrasphaera spp. Furthermore, FISH could detect no low-G + C Gram-positive bacteria in the communities of Runs P1, P2 and P3.

\section{Substrate assimilation and PHA production by community populations}

In samples of biomass from all three SBR runs, FISH/MAR showed that both the large and small $\beta$ proteobacterial coccobacilli that hybridized with the PAO651 probe assimilated acetate (Fig. 5a, b) and synthesized intracellular PHB anaerobically (Fig. 5c, d). They also accumulated phosphorus aerobically (Fig. 5e, $\mathrm{f}$ ), as did some of the high-G $+\mathrm{C}$ bacteria that fluoresced with the HGC69a probe (data not shown). The $\alpha$ proteobacterial 'G-bacteria', including Amaricoccus spp., and the $\gamma$-Proteobacteria also assimilated acetate and synthesized PHB anaerobically, but neither could accumulate phosphorus aerobically (data not shown). These results agree with a failure of these cells to stain metachromatically with methylene blue, which detects intracellular polyphosphate deposits (Lindrea et al., 1999). None of the bacterial populations in these communities assimilated glucose anaerobically by MAR, agreeing with results from the anaerobic glucose pulse experiments mentioned above.

\section{DISCUSSION}

The chemical trends detected in biomass samples during the aerobic-anaerobic SBR cycles in this study agree well with current models for the behaviour of EBPR systems, with acetate assimilation and $\mathrm{P}$ release occurring anaerobically followed by aerobic phosphorus uptake, changes which parallel anaerobic PHA synthesis and its subsequent aerobic re-utilization (Mino et al., 1998).

The microbial community composition in the SBRs operated with acetate as sole carbon source differed markedly from those seen in SBRs fed a mixture of glucose and acetate and showing no EBPR (Fig. 2), which were described by Kong et al. (2001). In the SBRs of Kong and colleagues, the tetrad-forming cocci or 'G-bacteria' dominated, whereas the $\beta$-Proteobacteria, which were dominant in the three EBPR biomasses described in this study, were numerically insignificant (Kong et al., 2001). Furthermore, two of the major populations of bacteria detected by Kong et al. (2001) in the SBRs showing no EBPR - i.e. the unidentified lacticacid-producing low-G $+\mathrm{C}$ Gram-positive bacteria and the high-G + C Gram-positive bacteria, many of which responded to the probe for $M$. glycogenica, a known glycogen-accumulating bacterium (Shintani et al., 2000) - either were not seen at all in the EBPR communities examined in this study or were only detected in small numbers.

The FISH/MAR data presented here strongly support the view that the Rhodocyclus-related bacteria are the major contributors to the EBPR recorded in SBRs and that they behave in accordance with current biochemical models. Their abundance at each feed $\mathrm{P} / \mathrm{C}$ ratio correlated well with both biomass phosphorus content and anaerobic phosphorus release (Fig. 4). These results, together with a failure to detect any Acinetobacter cells using FISH, add to the increasing body of data (Bond et al., 1999) that suggest the major PAB in EBPR activated sludge systems, including full-scale plants (Crocetti et al., 2000; Y. H. Kong \& R. J. Seviour, unpublished data), regardless of their geographical location or operational configuration, belong to the Rhodocyclus group. The FISH data also demonstrate that the Rhodocyclus-related $\mathrm{PAB}$ are pleiomorphic members of phylogenetically closely related populations, since all cells, regardless of their size, fluoresced with a single probe designed for this group (Crocetti et al., 2000).

FISH/MAR results suggested that the Rhodocyclusrelated bacteria were not the only PAB in our EBPR communities, since some of the high-G +C Grampositive bacteria could also accumulate phosphorus aerobically. However, numerically they contributed less to these microbial communities than in other (Bond et al., 1995, 1999; Kämpfer et al., 1996; Kawaharasaki et al., 1999; Liu et al., 2001; Wagner et al., 1994), if not all other, similar EBPR communities (e.g. Hesselmann et al., 1999). None of the Gram-positive PAB detected in this study appeared to be Tetrasphaera spp., which have been considered as potential PAB (Maszenan et al., 2000a) and were detected by FISH in an SBR EBPR community (Liu et al., 2001). Hence, the identity of the high-G $+\mathrm{C}$ Gram-positive PAB present in our system remains unknown.

Whereas the numbers of Rhodocyclus-related PAB were lower when the SBR was operated at the low P/C feed ratio, the numbers of $\alpha$-Proteobacteria and to a lesser 
extent $\gamma$-Proteobacteria, most of which possessed the 'G-bacteria' morphotype, increased (Fig. 2). The highest $\mathrm{P} / \mathrm{C}$ ratio at which EBPR still occurred here was 1:10; above this ratio EBPR failed (Y. H. Kong, unpublished data). Thus, high P removal was achieved even when ca $15 \%$ of the total bacterial cells in the community were the $\alpha$-proteobacterial ' $\mathrm{G}$-bacteria', which suggests that PAB and 'G-bacteria' can co-exist in EBPR systems. This agrees with observations made by Liu et al. (1996, 1997). It also questions whether these 'G-bacteria' necessarily indicate failing EBPR, although this question must remain unanswered until the identities of the ' $\mathrm{G}$ bacteria' in EBPR systems are satisfactorily resolved. It is not clear from our data whether the $\alpha$-proteobacterial 'G-bacteria' are a single phylogenetically homogeneous population or if they comprise a range of related but distinct bacteria. If the latter is true, then the changes seen in their numbers with different $\mathrm{P} / \mathrm{C}$ ratios may reflect a shift in the different populations within this group.

Equally importantly, as the numbers of $\alpha$-proteobacterial 'G-bacteria' increased with a lowered P/C ratio feed, the biomass glycogen levels also increased (Table 2). For example, in Runs P1, P2 and P3 the percentages of $\alpha$-Proteobacteria present (calculated from FISH analysis) were ca 15, 23 and $48 \%$, respectively, with biomass glycogen levels (expressed as a percentage of the total biomass content) of ca 8,12 and $17 \%(\mathrm{w} / \mathrm{w})$, respectively. The $\gamma$-Proteobacteria were at the limit of detection in the biomasses from Runs P1 and P2, where glycogen levels were also high, so these are unlikely to be the main bacteria responsible for biomass glycogen storage. The same argument would also apply to the high-G + C Gram-positive bacteria, including the known glycogen-accumulating bacterium $M$. glycogenica (Shintani et al., 2000) and the cocci of Crocetti et al. (2001) - neither of which were detected here by FISH. Furthermore, although the biochemical models suggest a role for glycogen synthesis in the PAB (Mino et al., 1998), the Rhodocyclus-related $\mathrm{PAB}$ were considered unlikely to be responsible for the increase in the glycogen content of the biomass, which corresponded to a drop in their numbers and an overall decrease in EBPR (Fig. 4). Thus, the evidence strongly suggests that it is the $\alpha$ proteobacterial ' $G$-bacteria' that are the major GAB responsible for the measured increases in biomass glycogen levels. However, from the FISH data neither Amaricoccus spp. nor Defluvicoccus vanus, previously isolated and characterized $\alpha$-proteobacterial 'G-bacteria' (Maszenan et al., 1997; A. M. Maszenan, unpublished data), were numerically important. It is possible that some of the $\alpha$-proteobacterial ' $G$-bacteria' seen in such large numbers in these communities are members of the genus Amaricoccus that do not respond to the FISH probes used here for members of this genus (Maszenan et al., 2000b), but instead represent undescribed bacteria (M. Beer, unpublished data). As well as being phylogenetically diverse, the $\alpha$-proteobacterial ' $G$ bacteria' seen in these aerobic-anaerobic SBR systems also appear to be physiologically different. None assimi- lated glucose anaerobically, yet most of those seen in the SBR communities with no EBPR could assimilate both glucose and acetate (Kong et al., 2001).

The decrease in Rhodocyclus-related $\mathrm{PAB}$ and the corresponding increase in the $\alpha$ - and $\gamma$-Proteobacteria at the low $\mathrm{P} / \mathrm{C}$ feed ratio was not accompanied by any discernible change in the acetate uptake rates of these communities (Table 2). These results contrast with those of Liu et al. (1996), who showed a much lower acetate uptake rate in a ' $\mathrm{G}$-bacteria'-dominated biomass than in one where the PAB dominated. They suggested that acetate uptake was an important determinant as to which of these populations ultimately dominated. This result might suggest that their 'G-bacteria' are different to those seen in this study. However, if the acetate uptake rate is not a key selective factor in determining the relative abundances of the PAB and 'G-bacterial' populations, as seems to be the case from these data, then the question as to what is remains unanswered.

\section{ACKNOWLEDGEMENTS}

An Australian Research Council Large Grant to R. J. Seviour supported this study. Y. H. Kong and M. Beer received La Trobe University PhD scholarships.

\section{REFERENCES}

Amann, R. I. (1995). In situ identification of micro-organisms by whole cell hybridization with rRNA-targeted nucleic acid probes. In Molecular Microbial Ecology Manual, part 3.3.6, pp. 1-15. Edited by A. D. L. Akkermans, J. D. van Elsas \& F. J. de Bruin. Dordrecht: Kluwer Academic.

Amann, R. I., Ludwig, W. \& Schleifer, K.-H. (1995). Phylogenetic identification and in situ detection of individual microbial cells without cultivation. Microbiol Rev 59, 143-169.

Bond, P. L., Hugenholtz, P., Keller, J. \& Blackall, L. L. (1995). Bacterial community structures of phosphate-removing and nonphosphate-removing activated sludges from sequencing batch reactors. Appl Environ Microbiol 61, 1910-1916.

Bond, P. L., Erhart, R., Wagner, M., Keller, J. \& Blackall, L. L. (1999). Identification of some of the major groups of bacteria in efficient and nonefficient biological phosphorus removal activated sludge systems. Appl Environ Microbiol 65, 4077-4084.

Cech, J. S. \& Hartman, P. (1993). Competition between polyphosphate- and polysaccharide-accumulating bacteria in enhanced biological phosphate removal systems. Water Res 27, 1219-1225.

Crocetti, G. R., Hugenholtz, P., Bond, P. L., Schuler, A., Keller, J., Jenkins, D. \& Blackall, L. L. (2000). Identification of polyphosphate-accumulating organisms and design of $16 \mathrm{~S}$ rRNA-directed probes for their detection and quantitation. Appl Environ Microbiol 66, 1175-1182.

Crocetti, G. R., Banfield, J. F., Keller, J., Bond, P. L. \& Blackall, L. L. (2001). The identification of glycogen accumulating organisms from a poorly-operating enhanced biological phosphorus removal laboratory-scale SBR. In Proceedings of the Third IW A International Conference on Microorganisms in Activated Sludge and Biofilm Processes, poster 172 on CD ROM. Edited by V. Tandoi, R. Passino \& C. M. Blundo. Rome: CNR.

Daims, H., Brühl, A., Amann, R., Schleifer, K.-H. \& Wagner, M. (1999). The domain-specific probe EUB 338 is insufficient for the detection of all Bacteria : development and evaluation of a more comprehensive probe set. Syst Appl Microbiol 22, 434-444. 
Falvo, A., Levantesi, C., Rossetti, S., Seviour, R. J. \& Tandoi, V. (2001). Synthesis of intracellular storage polymers by Amaricoccus kaplicensis, a tetrad forming bacterium present in activated sludge. J Appl Microbiol 91, 299-305.

Gray, N. D. \& Head, I. M. (2001). Linking genetic identity and function in communities of uncultured bacteria. Environ Microbiol 3, 481-492.

Hesselmann, R. P. X., Werlen, C., Hahn, D., van der Meer, J. R. \& Zehnder, A. J. B. (1999). Enrichment, phylogenetic analysis and detection of a bacterium that performs enhanced biological phosphate removal in activated sludge. Syst Appl Microbiol 22, 454-465.

Kämpfer, P., Erhart, R., Beimfohr, C., Böhringer, J., Wagner, M. \& Amann, R. (1996). Characterisation of bacterial communities from activated sludge: culture-dependent numerical identification versus in situ identification using group and genus-specific rRNAtargeted oligonucleotide probes. Microb Ecol 32, 101-121.

Kawaharasaki, M., Tanaka, H., Kanagawa, T. \& Nakamura, K. (1999). In situ identification of polyphosphate-accumulating bacteria in activated sludge by dual staining with rRNA-targeted oligonucleotide probes and 4',6-diamidino-2-phenylindol (DAPI) at a polyphosphate-probing concentration. Water Res 33, 257265.

Kong, Y. H., Beer, M., Seviour, R. J., Lindrea, K. C. \& Rees, G. N. (2001). Structure and functional analysis of the microbial community in an aerobic: anaerobic sequencing batch reactor (SBR) with no phosphorus removal. Syst Appl Microbiol 24, 597-609.

Lee, N., Nielsen, P. H., Andreasen, K. H., Juretschko, S., Nielsen, J. L., Schleifer, K.-H. \& Wagner, M. (1999). Combination of fluorescent in situ hybridization and microautoradiography - a new tool for structure-function analyses in microbial ecology. Appl Environ Microbiol 65, 1289-1297.

Lindrea, K. C., Seviour, E. M., Seviour, R. J., Blackall, L. L. \& Soddell, J. A. (1999). Practical method for the examination and characterization of activated sludge. In The Microbiology of Activated Sludge, pp. 257-293. Edited by R. J. Seviour and L. L. Blackall. Dordrecht: Kluwer Academic.

Liu, W. T., Mino, T., Nakamura, K. \& Matsuo, T. (1996). Glycogenaccumulating population and its anaerobic substrate uptake in anaerobic-aerobic activated sludge without biological phosphorus removal. Water Res 30, 75-82.

Liu, W. T., Nakamura, K., Matsuo, T. \& Mino, T. (1997). Internal energy-based competition between polyphosphate- and glycogenaccumulating bacteria in biological phosphorus removal reactors - effect of $\mathrm{P} / \mathrm{C}$ feeding ratio. Water Res 31, 1430-1438.

Liu, W. T., Nielsen, A. T., Wu, J. H., Tsai, C. S., Matsuo, T. \& Molin, S. (2001). In situ identification of polyphosphate- and polyhydroxyalkanoate-accumulating traits for microbial populations in a biological phosphorus removal process. Environ Microbiol 3, 110-122.

Manz, W., Amann, R., Ludwig, W., Wagner, M. \& Schleifer, K.-H. (1992). Phylogenetic oligonucleotide probes for the major subclasses of Proteobacteria: problems and solutions. Syst Appl Microbiol 15, 593-600.
Maszenan, A. M., Seviour, R. J., Patel, B. K. C., Rees, G. N. \& McDougall, B. M. (1997). Amaricoccus gen. nov., a Gram-negative coccus occurring in regular packages or tetrads, isolated from activated sludge biomass, and descriptions of Amaricoccus veronensis sp. nov., Amaricoccus tamworthensis sp. nov., Amaricoccus macauensis sp. nov., and Amaricoccus kaplicensis sp. nov. Int J Syst Bacteriol 47, 727-734.

Maszenan, A. M., Seviour, R. J., Patel, B. K. C., Schumann, P., Burghardt, J., Tokiwa, Y. \& Stratton, H. M. (2000a). Three isolates of novel polyphosphate-accumulating Gram-positive cocci, obtained from activated sludge, belong to a new genus, Tetrasphaera gen. nov., and description of two new species, Tetrasphaera japonica sp. nov. and Tetrasphaera australiensis sp. nov. Int J Syst Evol Microbiol 50, 593-603.

Maszenan, A. M., Seviour, R. J., Patel, B. K. C. \& Wanner, J. (2000b). A fluorescently-labelled r-RNA targeted oligonucleotide probe for the in situ detection of G-bacteria of the genus Amaricoccus in activated sludge. J Appl Microbiol 88, 826-835.

Meier, H., Amann, R., Ludwig, W. \& Schleifer, K.-H. (1999). Specific oligonucleotide probes for in situ detection of a major group of Gram-positive bacteria with low DNA G + C content. Syst Appl Microbiol 22, 186-196.

Mino, T., van Loosdrecht, M. C. M. \& Heijnen, J. J. (1998). Microbiology and biochemistry of the enhanced biological phosphate removal process. Water Res 32, 3192-3207.

Neef, A., Witzenberger, R. \& Kämpfer, P. (1999). Detection of sphingomonads and in situ identification in activated sludge using $16 \mathrm{~S}$ rRNA-targeted oligonucleotide probes. J Ind Microbiol Biotechnol 23, 261-267.

Nielsen, A. T., Liu, W. T., Filipe, C., Grady, L., Jr, Molin, S. \& Stahl, D. A. (1999). Identification of a novel group of bacteria in sludge from a deteriorated biological phosphorus removal reactor. Appl Environ Microbiol 65, 1251-1258.

Roller, C., Wagner, M., Amann, R., Ludwig, W. \& Schleifer, K.-H. (1994). In situ probing of Gram-positive bacteria with high DNA $\mathrm{G}+\mathrm{C}$ content using $23 \mathrm{~S}$ rRNA-targeted oligonucleotides. Microbiology 140, 2849-2858.

Seviour, R. J., Maszenan, A. M., Soddell, J. A., Tandoi, V., Patel, B. K. C., Kong, Y. H. \& Schumann, P. (2000). Microbiology of the 'G-bacteria' in activated sludge. Environ Microbiol 2, 581-593.

Shintani, T., Liu, W. T., Hanada, S., Kamagata, Y., Miyaoka, S., Suzuki, T. \& Nakamura, K. (2000). Micropruina glycogenica gen. nov., sp. nov., a new Gram-positive glycogen-accumulating bacterium isolated from activated sludge. Int J Syst Evol Microbiol 50, 201-207.

Wagner, M., Erhardt, R., Manz, W., Amann, R., Lemmer, H., Wedi, D. \& Schleifer, K.-H. (1994). Development of an rRNA-targeted oligonucleotide probe specific for the genus Acinetobacter and its application for in situ monitoring in activated sludge. Appl Environ Microbiol 60, 792-800.

Received 21 December 2001; revised 27 March 2002; accepted 4 April 2002. 